\title{
Beginnings of the Piano Department at the Belgrade Music Academy
}

\author{
Ivana Medić \\ Srbska akademija znanosti in umetnosti \\ Serbian Academy of Sciences and Arts
}

\section{Foundation of the Belgrade Music Academy and its Piano Department}

Prior to the establishment of the first tertiary educational institution for studying music, the Belgrade Music Academy in 1937, there were two music schools in Belgrade: "Mokranjac" (previously Belgrade Music School, founded in 1899 by the Belgrade Singing Society) ${ }^{\mathrm{I}}$ and "Stanković" (founded in 1911 by the eponymous singing society). ${ }^{2}$ Ever since the end of the Great War, there were initiatives to transform this private domain into public and to establish a state-funded music conservatory. ${ }^{3}$ Indeed, both schools had ambitions to expand into conservatories; "Stanković" accomplished this feat in the early 1930 s during Emil Hajek's tenure as the school principal ${ }^{4}$ - albeit, still without a comprehensive state support. On the other hand, in

1 A detailed history of music education in Belgrade before and after the foundation of the music school "Mokranjac" is presented in the article by Stana Đurić-Klajn, published in the festive monograph on occasion of the school's 75th anniversary: Stana Đurić-Klajn, "Muzičko školovanje u Srbiji do 1914. godine" [Music Education in Serbia until 1914], in: Muzička škola "Mokranjac" 1899-1974 [Music School "Mokranjac" 1899-1974], ed. Vera Zečević (Belgrade: Music School "Mokranjac", 1974), 11-41. The school has been active to the present day; its official website is https://mokranjacbg.rs.

2 Radmila Pejović, “About School,” http://msstankovic.edu.rs/aboutschool.html.

3 Cf. Miloje Milojević, “O muzikalnom vaspitanju” [On Music Education], Part I, Prosvetni glasnik 1 (1920): 19-27; Part II, Prosvetni glasnik 3 (1920): 150-156. Pejović, "About School," http://msstankovic.edu.rs/aboutschool.html. 
1925 Jovan Zorko, the principal of the "Mokranjac" music school, submitted a request to the Ministry of Education to upgrade the school to the level of conservatory, but the Ministry rejected it, on the basis that logistic requirements were not met; moreover, they again rejected the school's request to become nationalized. ${ }^{5}$ This reluctance of the Ministry of Education to nationalize private music schools in Belgrade and to upgrade their status created a stark contrast to the situation in other Yugoslav cultural centers, Zagreb and Ljubljana, where the existing music schools were nationalized and elevated to the level of conservatories after the Great War. Therefore, ambitious students from Belgrade and other Serbian towns who wished to continue their music education at the tertiary level were forced to move either to Zagreb or Ljubljana, or to big European centres such as Paris, Vienna, Prague, Berlin, Munich, Leipzig, Rome etc., which had a long-standing tradition of tertiary music education.

By the year 1937 Belgrade, then the capital city of the Kingdom of Yugoslavia, already had over 300.000 inhabitants. Such a rapid demographic growth, and the cultural demands of the new, urban populace, resulted in the establishment of many cultural institutions in short succession - among them, Belgrade Philharmonic Orchestra, Orchestra of the Music Society "Stanković", Opera and Orchestra of Serbian National Theatre, Orchestra of the Belgrade Music Society, Chamber Orchestra Collegium Musicum, and the Great Orchestra of Radio Belgrade; ${ }^{6}$ this list could be expanded by mentioning numerous choral societies and amateur ensembles. It is immediately obvious that the demand for professional musicians - be it instrumentalists, singers, conductors or composers-arrangers - was constantly increasing; hence the establishment of the Music Academy became a necessity.

Đurić-Klajn, "Muzičko školovanje u Srbiji do 1914. godine," 62.

6 On the establishment and development of these institutions, see: Živojin Zdravković et al., Beogradska filharmonija 1923-1973 [The Belgrade Philharmonics 1923-1973] (Belgrade: The Belgrade Philharmonics, 1977); Stana Đurić-Klajn, Akordi prošlosti [Chords of the Past] (Belgrade: Prosveta, 1981); Stanojlo Rajičić, ed., 125 godina Narodnog pozorišta u Beogradu [125th Anniversary of the National Theatre in Belgrade] (Belgrade: Serbian Academy of Sciences and Arts, 1997); Roksanda Pejović, Koncertni život u Beogradu (1919-1941) [Concert Life in Belgrade (1919-1941)] (Belgrade: Faculty of Music, 2004); Ivana Medić, ed., Radio i srpska muzika [Radio and Serbian Music] (Belgrade: Institute of Musicology SASA, 2015); Ivana Perković, ed., Naših 80 godina - Kultura sećanja [Our 8o Years - The Culture of Remembrance] (Belgrade: Faculty of Music, 2018). 
On 31 March 1937 the Decree of the establishment of the state-sponsored secondary and tertiary art schools in Belgrade was passed, and in September 1937 the first candidates passed entrance exams for the Academy. ${ }^{7}$ The Secondary Music School and the Academy shared the same building situated in Park Manjež in Belgrade - the word "manjež" meaning "school for horsemen." The building itself was completed in 1931 as an auxiliary building for the National Assembly. Although adapted to host the Academy, it was planned from the outset that it would be just a temporary solution, until the new, purpose-built edifice of the Academy was erected; ${ }^{8}$ however, this plan was never realised and, as of 2019, the Academy is still located in the same building!

The Academy was officially opened on 21 November 1937, in the presence of the political and cultural elite of that time (but without the attendance of either King Peter II, President Milan Stojadinović or Minister of Education Dimitrije Magarašević - all of whom had sent only their emissaries). ${ }^{9}$

Three professors prepared the curricula for all departments and rulebooks for professors' and students' conduct: first of all, Kosta P. Manojlović (1890-1949), composer and musicologist, an alumnus of the University of Oxford and the first Dean of the new Academy, who had previously taught at the Belgrade Music School and the Faculty of Orthodox Theology of the University of Belgrade. ${ }^{\circ}$ The second member of this triumvirate was Stevan Hristić (1885-1958), composer and conductor, who had served as the Director of Opera of the National Theatre in Belgrade. ${ }^{I I}$ The third member

7 Cf. Ivana Perković, “Dva početka. Godine 1937-1957” [Two Beginnings. Years 19371957], in Naših 80 godina - Kultura sećanja, ed. Ivana Perković (Belgrade: Faculty of Music, 2018), 22.

8 Cf. Ivana Perković, “Trajni déjà vu. Beleške o prvim godinama rada Muzičke akademije u Beogradu, povodom jubileja Fakulteta muzičke umetnosti” [Permanent déjà vu. Notes on the First Years of Work of the Music Academy in Belgrade, on the Occassion of the Anniversary of the Faculty of Music], Zbornik Matice srpske za scenske umetnosti i muziku 57 (2017): 205.

Kosta P. Manojlović, ed., Muzička akademija u Beogradu - Academia artium musicarum Belgradensis [Music Academy in Belgrade], Annual report for the first academic year 1937/38 (Belgrade: Music Academy, 1938), 15-16.

10 On Manojlović's life and work, see various studies at the first English-language collection dedicated to him: Vesna Peno, Ivana Vesić, and Aleksandar Vasić, eds., Kosta P. Manojlović (1890-1949) and the Idea of Slavic and Balkan Cultural Unification (Belgrade: Institute of Musicology SASA, 2017).

11 On Hristić's life and work see: Dimitrije Stefanović, ed., Život i delo Stevana Hristića [The Life and Work of Stevan Hristić] (Belgrade: Serbian Academy of Sciences and Arts, 1991). 
was Petar Stojanović (1877-1957), an acclaimed violinist of international renown, who had previously worked as professor and director of the Music School "Stanković". ${ }^{2}$ Whilst preparing the official documents for the newly established Academy, Manojlović, Hristić and Stojanović relied upon the curricula and rulebooks of the academies in Ljubljana and Zagreb. ${ }^{13}$ The Secondary Music School attached to the Academy was intended to educate teachers who would teach music at elementary schools, and it also served as a pool for recruitment of students for the Academy. Studies of composition and conducting were conceived to last five years (10 semesters), while studies at all other departments lasted four years (8 semesters).

Ivana Perković cites a 1938 newspaper article about the working conditions at the newly established Academy:

Today the academy is situated in a large building. It has the most modern classrooms, 13 grand pianos of the best worldwide brands, a musical library with 2600 volumes and an archive. ${ }^{14}$

As testified by Branko Kozarski and relayed by Dubravka Jovičić, the very first pianos that arrived to the Academy were actually donations of wealthy families: according to this testimonial (which supplements the official preserved documents about the purchase of instruments), upon visiting the newly opened Academy, Prince Pavle [Paul] Karađorđević (then serving as the deputy monarch, in lieu of the underage King Petar [Peter] II) was disappointed by the state of the instruments and he himself donated 10 new Stainway pianos. ${ }^{15}$ On the other hand, in her article dedicated

12 On Stojanovićs life and work see: Biljana Milanović, "Reaffirmation of the Forgotten Serbian Music: Three Sonatas of Petar Stojanović for One String Instrument and Piano," CD Booklet Sonatas of Petar Stojanović (Belgrade: Serbian Musicological Society, 2019), 5-19; Biljana Milanović, "Proučavanje umetničke biografije i muzičkog delovanja Petra Stojanovića: prilog identifikaciji i razmatranju istraživačkih izvora” [The Study of Artistic Biography and Musical Activities of Petar Stojanović: A Contribution to the Identification and Consideration of Research Sources], Zbornik Matice srpske za scenske umetnosti i muziku 61 (2019): forthcoming; Biljana Milanović, ed., Na marginama muzikološkog kanona: kompozitorska generacija Petra Stojanovića, Petra Krstića i Stanislava Biničkog [On the Margins of the Musicological Canon: The Generation of Composers Petar Stojanović, Petar Krstić and Stanislav Binički] (Belgrade: Serbian Musicological Society and the Institute of Musicology SASA, 2019). Rulebooks and policies of the Academy were published in its first annual report: Manojlović, Muzička akademija u Beogradu, 93-108.

14 Cited in: Perković, “Dva početka. Godine 1937-1957," 26.

15 Dubravka Jovičić, "Katedra za klavir" [The Department for Piano], in Naših 80 godina - Kultura sećanja [Our 8o Years - The Culture of Remembrance], ed. Ivana Perković (Belgrade: Faculty of Music, 2018), 152. 
to the early years of the Academy, Ivana Perković reproduces an archival document about the purchase of three grand pianos "by the best brands"; ${ }^{16}$ in addition to ten pianos gifted by Prince Pavle, that would bring the total number of grand pianos at the Academy to 13 - as indeed confirmed by the newspaper article cited above. Unbelievably, some of these Stainway pianos acquired in 1937 are still used at the Academy up to this day!

Emil Hajek, the long-standing Head of the piano department, wrote in 1962:

The environment in which the Music Academy in Belgrade began to work in 1937 was beautiful, attractive and stimulating. The building assigned to host the academy was carefully and skillful$l y$ adapted for the new purpose, and the first Dean, Kosta Manojlovic, managed to secure considerable funds for its external and internal equipment. [...] Teachers at the piano department were most inspired and excited by a set of first-rate grand pianos, produced by the world's leading companies. I think that, when it comes to pianos, at that time the Music Academy in Belgrade was the best equipped music-educational institution in Europe. ${ }^{17}$

Hajek then regretfully remarked that the ensuing World War II, which brought about the destruction and impoverishment of the country, resulted in the Academy being unable to maintain such high standards established in its earliest days. ${ }^{18}$

\section{Teaching Staff at the Piano Department and Their Pianistic Upbringing}

Aside from the three founding fathers of the Academy - Manojlović, Hristić and Stojanović - five additional professors were recruited until December 1937. Three of those five were hired to teach piano: Emil Hajek and Ciril Ličar as Associate Professors, and Jelica Krstić (Popović) as Junior (Assistant) Professor - thus the piano department immediately became the biggest one. ${ }^{19}$ Additionally, three pianists were hired to teach piano full-time

16 See Perković, “Dva početka. Godine 1937-1957," 30.

17 Emil Hajek, "Perspektive mladih pijanista" [Perspectives of Young Pianists], in Dvadeset pet godina Muzičke akademije u Beogradu 1937-1962 [Twenty-Five Years of the Music Academy in Belgrade 1937-1962], ed. Predrag Milošević (Belgrade: Music Academy, 1962), 45.

18 Ibid.

19 Manojlović, Muzička akademija u Beogradu, 43. 
at the secondary school: Alisa Bešević, Stanica Botorić and Ljubica Maržinec; ${ }^{20}$ and another three were employed as honorary piano teachers at the secondary school: Jelena Nenadović, Stanojlo Rajičić (who would later become Professor of Composition) and Danica Stanisavljević. ${ }^{21}$ In subsequent years they would be joined by Olga Mihailović Milošević (in 1939), Miroslava Mokranjac (in 1940), Desanka Velimirović (in 1944) and Milka Đaja (in 1945), and some of the teachers previously employed at the Secondary music school would also transfer to teach at the Academy. ${ }^{22}$ Except for Stanica Botorić, all of those professors remained at the Academy until they retired. The Ministry of Education had a final say as to the appointment of teaching staff, sometimes opposing the recommendations and decisions of the Professors' Council of the Academy. ${ }^{23}$ Many of the newly appointed professors of piano had previously taught at music schools "Mokranjac" and "Stanković", hence both schools were left in peril, not the least because those who transferred to the Academy were the most experienced and distinguished professors. $^{24}$

After the end of World War II and in subsequent years, the first group of young assistants, members of the first generations who graduated from the Belgrade Music Academy joined the piano department: Milica Stojanović Marjanović, Vera Veljkov Medaković, Vlastimir Škarka, Arsen Triva, Olga Dušanić Popov, Dušan Trbojević, Olivera Đurđević, Katarina Aćimović and Darinka Mihailović Pavlović. ${ }^{25}$ Other professors who joined the piano department after the war were Andreja Preger (educated in Leipzig), as well as Melita Lorković, Stanka Vrinjanin Hiršl and Mirjana Vukdragović, all three of them graduates of the Music Academy in Zagreb, in the class of the acclaimed professor Svetislav Stančić.

20 Ibid.

21 Ibid., 44.

22 See the list of the teaching staff at the Academy in the period from 1937 to $1961 \mathrm{in}$ : Predrag Milošević, ed., Dvadeset pet godina Muzičke akademije u Beogradu 19371962 [Twenty-Five Years of the Music Academy in Belgrade 1937-1962] (Belgrade: Music Academy, 1962), 98-103.

23 See Perković, “Trajni déjà vu,” 210.

24 On the circumstances in which "Mokranjac" resumed its work after a major loss of its teaching staff, see: Vera Zečević, "Škola od 1914. do 1948. godine” [The School from 1914 to 1948], in Muzička škola "Mokranjac" 1899-1974 [Music School "Mokranjac" 1899-1974], ed. Vera Zečević (Belgrade: Music School "Mokranjac”, 1974), 64. Jovičić, "Katedra za klavir," 143. 
Let us briefly overview professional biographies of the first piano teachers and their pianistic upbringing, in order to show which pianistic traditions they were representing:

Emil Hajek (1886-1974) was a pianist of Czech origin from Austria-Hungary. He graduated from the Prague Conservatory in 1908, under the tuition of prof. Josef Jiránek (1855-1940); he also studied organ and composition with Antonín Dvořák. His piano teacher Jiránek was the disciple of Karel Smetana, brother of Bedřich Smetana, who continued his studies in Kharkov (nowadays in Ukraine). Jiránek favoured the repertoire of Czech composers, especially Smetana, while his pianistic style was shaped by his Russian training; he passed on this pianistic tradition onto his students, including Hajek. After graduating in Prague, Hajek continued his piano study in Berlin. Between 1909-1921 he taught piano and chamber music at Saratov and performed as piano accompanist to Jan Kubelik. He moved to Belgrade in 1928, where he became the director of the Music school "Stanković, which he elevated to the level of the conservatory. As asserted by Katarina Tomašević:

The arrival of the Czech pianist Emil Hajek [Hayek] [...] represented a turning point. With Hayek, whose name was widely recognised in Europe, Belgrade got a complete musician, who had already achieved a successful concert career [...] Hayek had been the Rector of the Saratov conservatory for eleven years, where he achieved fame as a piano professor. After taking up the position as head of the piano department in "Stankovic', he took several key steps: he founded the Concert Department; harmonised marking criteria with the European ones; [...] and reformed the curriculum, encouraging the introduction of a contemporary Slav and especially national repertoire. Setting a personal example to colleagues, he actively staged solo concerts, accompanied prominent foreign guests and collaborated with other musicians in chamber music concerts. ${ }^{26}$

From 1937 until 1963 Hajek was a full professor and Head of the piano department at the Music Academy of Belgrade, utilizing his vast pedagog-

26 Katarina Tomašević, "Musical Life in Serbia in the First Half of the 2oth Century: Institutions and Repertoire," in Serbian and Greek Art Music: A Patch to Western Music History, ed. Katy Romanou (Bristol/Chicago: Intellect Books, 2009), 45-46. 
ical and managerial experience; and he also served as the first president of the Serbian Society of Musicians. ${ }^{27}$

The second professor, Ciril Ličar (1894-1957) was of Slovenian ethnicity. He studied piano at the school of Glasbena matica in Ljubljana, and then continued at the Prague Conservatory. From 1921-1925 he taught at the secondary school of the music academy in Zagreb, and in 1925 he moved to Belgrade. He taught at the music school "Mokranjac" and in 1937 became a professor at the newly established Academy.

Ljubica Maržinec began her study of piano with Ciril Ličar in Belgrade, and then continued at the Master School of the Prague Conservatory with professor Karel Hoffmeister, while Jelica Krstić (Popović) began her piano study at the Belgrade Music School and continued her studies at the École Normale de Musique in Paris, with professor Isidor Philipp (1863-1958). Another student of Prof. Philipp in Paris was Milka Đaja, who graduated piano in Vienna, and then continued her studies in Paris. Isidor Philipp was a French pianist of Jewish Hungarian descent. He was a student of one Georges Mathias, himself the best student of Frédéric Chopin. As most of Chopin's students were amateurs, or died early, Mathias was the only one who could pass on his pedagogical legacy. Isidor Philipp carried on Chopin's philosophy of teaching; his students commented that he insisted on suppleness, firmness, rhythmic exactitude and articulation. Thus Jelica Krstić and Milka Đaja brought Chopen's refined Parisian piano school to Belgrade and passed on this tradition to their students.

Stanica Botorić, married Mihailović, was the daughter of Svetozar Botorić (1857-1916), a famous Serbian hotelier who perished in a labour camp near Vienna during the Great War. Her mother Slavka sent all of her three children to be educated abroad: the youngest daughter Stanica graduated piano at the École normale supérieure in Paris in the class of Alfred Cortot and received the highest diploma "Licence de concert". Upon return to Belgrade she taught at the Music Academy since its inception in 1937, until she was dismissed from her post by Emil Hajek and the new communist officials in 1945. Years later she confessed:

I asked why I was being fired; they told me 'You belong to a bourgeois family and you are undesirable to teach students'. The govern-

27 Biographies of all professors of the Belgrade Music Academy and their teachers (except where noted otherwise) are adapted from: Manojlović, Muzička akademija u Beogradu, 51-72; Various authors, Muzička enciklopedija [Music Encyclopedia] (Zagreb: Jugoslavenski leksikografski zavod, 1971). 
ment took all our properties. We became a doomed family, people were afraid to visit us ... ${ }^{28}$

After her husband Petar was killed in 1950, Stanica Mihailović left Yugoslavia for France, in search of employment; she was separated from her young son Ljubomir for 18 months, until he was finally granted a passport by the Yugoslav authorities. ${ }^{29}$

As a pianist and piano teacher, Jelena Nenadović merged two schools, Czech and French, because she studied initially at the Master School of the Prague Conservatory with Ljubica Maržinec's professor Karel Hoffmeister, and then she won a two-year stipend of the French government to study with Lazare-Lévy at the Paris Conservatory. On the other hand, Danica Stanisavljević studied first at the Music Academy in Vienna, and then in Paris, at the École normale. The influence of French pianists such as Alfred Cortot and Lazare-Lévy was also brought to Belgrade by pianists Olga Mihailović Milošević and Vera Veljkov Medaković respectively, who would join the department during the first decade after World War II.

Alisa Bešević was a Russian pianist from St Petersburg who studied piano in Rome, at the Academy of St. Cecilia. In Rome, she met Serbian painter Nikola Bešević and married him. They returned to Belgrade in 1924; he took up work at the Art School in Belgrade, while she taught at the Music School ("Mokranjac") from 1927 to 1937, when she transferred to the Secondary School of the Music Academy.

Svetislav Stančić (1895-1970), whose students were three professors appointed at the Belgrade academy after the end of World War II (Melita Lorković, Stanka Vrinjanin Hiršl and Mirjana Vukdragović) was a Croatian pianist, composer and teacher of Serbian descent, who became the founder of the acclaimed Zagreb piano school. He studied piano privately with Heinrich Barth - the last pupil of Franz Liszt - and Conrad Ansorge in Berlin, and composition with Feruccio Busoni at the Meister school of the Berlin Academy of Arts. Upon his return to Zagreb he was a full professor of piano at the Music Academy in Zagreb and Head of the piano department (1927-8, 1935-41 and 1945-67) with a break between 1941 and 1945 when, as an ethnic Serb in the Independent State of Croatia [NDH] he was not al-

28 Mirjana Sretenović, “Tragična sudbina porodice Botorić” [The Tragic Destiny of the Botorić Family], Politika, February 28, 2018, http://www.politika.rs/sr/clanak/399218/Kultura/Tragicna-sudbina-porodice-Botoric. 
lowed to work. ${ }^{30}$ Stančić set the new high standards in the piano pedagogy and directed the Croatian piano school towards a high level of professionalism, a monumental Lisztian technique and a penchant for German and Austrian classical and romantic repertoires. Lorković, Vrinjanin and Vukdragović then passed on this Lisztian legacy onto their Belgrade students.

As we can see, the newly-established piano department of the Belgrade academy became a melting pot of several traditions - Russian, Czech, French, Italian and, after the war, German. Among others, the department hired professors who were pianistic descendants of the greatest nineteenth-century pianists, Chopin and Liszt. This explains why the piano department at the Belgrade Academy set a very high standard right from the outset and never abandoned it. This is confirmed in Emil Hajek's recollections:

The department is mixed in terms of the professors' place and type of education and, due to this, different methodological approaches to the principles of piano teaching. Each one of them is given the opportunity to apply, develop, correct and perfect their teaching method, and to build their reputation on the basis of success of their students. There is no monopoly of a single pedagogical method. Yet, there is a common goal: the work discipline of students, a constant improvement of purposeful technical habits based on the natural features of our physical (bodily) mechanism, and their application for the purpose of achieving a technically immaculate performance, faithful to the composer's idea. ${ }^{31}$

\section{The First Students of the Piano Department; Requirements and Curriculum}

The opening of the Academy did not result in an immediate surge of prospective students. Not only was the broad public poorly informed of the purpose of the new institution, but, as described by Emil Hajek, the two Belgrade music schools, "Mokranjac" and "Stanković", "kept their best students by telling them that the Academy will not offer them anything better than what they had already learned at these schools. ${ }^{32}$ Still, soon it became

See Stančićs biography at the website of Croatian Music Information Centre: "Svetislav Stančić," Croatian Music Information Centre, http://quercus.mic.hr/quercus/person/1211.

31 Hajek, "Perspektive mladih pijanista," 52-53.

32 Ibid., 46. 
clear that Academy was the necessary final stage in the professional education of musicians - not least because it was accessible to students who could not afford the expensive music studies abroad.

As described by Hajek, the curriculum of the Academy was written with an aim to offer its students the maximum of knowledge and skills necessary to produce comprehensively educated musicians; hence the curriculum prescribed that all students of the academy should study music-theoretical subjects, as well as piano. The piano department had three categories of students: (1) those who studied piano as their major; (2) those who studied the teachers' department with piano as their secondary subject; (3) students of all other departments who studied complementary piano. Hajek also testified that the activities of the Secondary music school were tightly intertwined with those of the Academy: the majority of professors of the Academy also taught at the Secondary school, thus ensuring the continuity of teaching and a stimulative environment for the youth. ${ }^{33}$

Table r: The first students of the piano department

\begin{tabular}{lll}
\multicolumn{1}{c}{ Name of the student } & \multicolumn{1}{c}{ Place of birth } & \multicolumn{1}{c}{ Professor at the Academy } \\
\hline Batugovska Marija & Arhangelsk (Russia) & Emil Hajek \\
\hline Vejnštejn Olga & Botoșani (Romania) & Ciril Ličar \\
\hline Ilić Milica & Paris (France) & Emil Hajek \\
\hline Dušanić Olga & Budapest (Austria-Hungary) & Jelica Krstić (Popović) \\
\hline Koen Luna & Beograd & Emil Hajek \\
\hline Radivojević Milica & Pančevo (Dunavska banovina) & Emil Hajek \\
\hline Stojanović Milica & Osijek (Savska banovina) & Emil Hajek \\
\hline Ćorović Ljiljana & Dubrovnik (Zetska banovina) & Ciril Ličar \\
\hline Škarka Vlastimir & Beograd & Emil Hajek \\
\hline
\end{tabular}

The first generation of students enrolled at the Music Academy in 1937 consisted of 39 students; among them, 9 students passed the entrance exam to study piano. According to the 1962 Annual of the Music Academy, out of those 39, a total of 20 students graduated, including 6 pianists: Milica Stojanović (Marjanović), Milica Radivojević, Olga (Dušanić) Popov, Olga Vejnštajn, Vlastimir Škarka and Luna Koen (Puđa). Among them only Milica Stojanović managed to graduate before the outbreak of war, while the remaining five prolonged their studies. Table 1 contains the names of the first generation of piano students, their places of birth and the names of pi33 Ibid., 45-46. 
ano professors they worked with. ${ }^{34}$ As the table shows, only two out of these nine were Belgrade natives - Vlastimir Škarka, a descendant of a Czech family of musicians resident in Belgrade since the turn of the twentieth century, and Luna Koen (married Puđa), an offspring of a Jewish family from Belgrade. The remaining students were born in Arhangelsk, Botoșani, Paris, Budapest, Pančevo, Osijek and Dubrovnik - and it is likely that they had begun their piano education in those cities, before moving to Belgrade to study at the Academy.

Table 2 contains the list of students at the piano department who enrolled between 1937 and 1945 and managed to graduate - a total of 33 pianists. The table was compiled using the records from all festive publications released on occassions of the important anniversaries of the Academy; since there are some inaccuracies and inconsistencies in those publications, I have attempted to rectify them. The table also shows when these students graduated and whether they embarked on a teaching career; as we can see, a majority of them indeed found their calling as piano teachers or accompanists. Due to the fact that female graduates married and changed their surnames, sometimes it was not possible to locate where they continued to work after graduation. The number of pianists who graduated at the department remained within single-digit numbers until the late 1950 - only in the academic year 1958/59 it increased to 14 graduates.

Table 2: List of piano graduates enrolled before 1945

\begin{tabular}{lcrll}
\multicolumn{1}{c}{$\begin{array}{l}\text { Surname and name } \\
\text { Stojanović (Marjanović) }\end{array}$} & Enrolled & Graduated & \multicolumn{1}{c}{ Later teaching career } \\
Milica & $1937 / 38$. & $1940 / 41$. & Piano Professor at the Academy \\
\hline (Bogdanov Vera & $1937 / 38 . ?$ & $1940 / 41 . ? \begin{array}{l}\text { Probably a student at the music pedagogy } \\
\text { department, not piano) }\end{array}$ \\
\hline Škarka Vlastimir & $1937 / 38$. & $1941 / 42$. & Piano Professor at the Academy \\
\hline Dušanić (Popov) Olga & $1937 / 38$. & $1941 / 42$. & Piano Professor at the Academy \\
\hline Radivojević Milica & $1937 / 38$. & $1941 / 42$. & \\
\hline Vejnštajn Olga & $1937 / 38$. & $1942 / 43$. & \\
\hline Koen (Puđa) Luna & $1937 / 38$. & $1952 / 53$. & Active as a composer \\
\hline Veljkov (Medaković) Vera & $1938 / 39$. & $1941 / 42$. & Piano Professor at the Academy \\
\hline Aćimović Katarina & $1939 / 40$. & $1945 / 46$. & Piano Professor at the Academy \\
\hline Pavlović Mirka & $1939 / 40$. & $1945 / 46$. & Worked as a musicologist \\
\hline Dojčinović Branka & $1939 / 40$. & $1945 / 46$. & Pianist \\
\hline Ristović Mirjana & $1940 / 41$. & $1944 / 45$. & Piano prof. in Sombor \\
\hline Smodlaka Jelica & $1940 / 41$. & $1945 / 46$. & \\
\hline
\end{tabular}




\begin{tabular}{|c|c|c|c|}
\hline Surname and name & Enrolled & Graduated & Later teaching career \\
\hline Milosavljević Mileva & $1940 / 41$ & $1946 / 47$ & \\
\hline Triva Arsen & $1941 / 42$ & $1945 / 46$ & Piano Professor at the Academy \\
\hline Votrubec Sonja (Sofija) & $1941 / 42$ & $1945 / 46$ & moved to Australia \\
\hline Đorđević Nadežda & $1941 / 42$ & $1945 / 46$ & \\
\hline Šišmanović Dušica & $1941 / 42$ & $1945 / 46$ & Prof. - Music School "Slavenski" \\
\hline Dragić Aleksandar & $1941 / 42$ & $1947 / 48$ & \\
\hline Zrnić Desanka & $1942 / 43$ & $1946 / 47$ & Accompanist at Secondary school \\
\hline Popović Zagorka & $1942 / 43$ & $1946 / 47$ & \\
\hline Simonović Ivanka & $1942 / 43$ & $1946 / 47$ & Piano prof. at Secondary school \\
\hline Jovanović Kosara & $1942 / 43$ & $1948 / 49$ & Accompanist at the Academy \\
\hline Živković Mirjana & $1942 / 43$ & $1948 / 49$ & \\
\hline Mokranjac Vasilije & $1942 / 43$ & $1948 / 49$ & Composer, Prof. at the Academy \\
\hline Stojanović Daroslava & $1943 / 44$ & $1946 / 47$ & \\
\hline Jovanović Olga & $1943 / 44$ & $1947 / 48$ & Prof. - Music School "Vučković" \\
\hline Manojlović Gordana & $1943 / 44$ & $1949 / 50$ & $\begin{array}{l}\text { Daughter of Kosta Manojlović } \\
\text { Piano prof. at secondary school }\end{array}$ \\
\hline Petrović Miroslava & $1943 / 44$ & $1949 / 50$ & Prof. - Music School "Slavenski" \\
\hline Stakić Veroslava & $1943 / 44$ & $1949 / 50$ & Piano prof. at Secondary school \\
\hline Tasić Dobrila & $1943 / 44$ & $1949 / 50$ & \\
\hline Čabrić (Leandrov) Tatjana & $1943 / 44$ & $1953 / 54$ & Accompanist at Secondary school \\
\hline Siber (Jorgović) Bosiljka & $1944 / 45$ & $1949 / 50$ & \\
\hline
\end{tabular}

As to the code of conduct at the Academy, students had to adhere to strict rules regarding their attendance and absence, the use of the library, etc. ${ }^{35}$ Students were prohibited from booking independent public performances, for the fear of damaging the reputation of the academy - they needed a written permission granted by the Dean and the professor in whose class they were studying; moreover, they were banned from writing newspaper reviews. ${ }^{36}$ The repertoire required to be performed at the graduation exam in piano during the first years of the Academy was practically the same as it is today: it consisted of a piano recital with one or two virtuoso etudes, one polyphonic piece, a sonata, an important romantic piece, a modern work and a piece by a domestic composer; plus, a concerto for piano and orchestra. ${ }^{37}$ The rules regarding the final exams were very strict: students who failed to pass at least one exam had to repeat the entire year; and they were only allowed to repeat the year once. ${ }^{38}$ These high standards

\footnotetext{
35 Ibid., 93-108.

36 Ibid., 94 .

37 See one graduation programme reproduced at Perković, "Dva početka. Godine 1937-1957," 28.

38 Manojlović, Muzička akademija u Beogradu, 101.
} 
had to be relaxed during the German occupation of Belgrade, due to the damage made to the building during the bombing in the spring of 1941; the exile or imprisonment of some professors and students; the refusal of the Ministry of Education to pay remuneration to honorary professors (some of whom continued to work for free); the lack of heating in the building; frequent epidemics of contagious diseases such as diphtheria; not to mention that the German forces seized some pianos for their own needs. ${ }^{39}$ Nevertheless, the Ministry of Education and the directorium of the Academy agreed that this institution should continue its work and play an active role in the artistic life of the occupied country and its capital city.

As testified by Dušan Trbojević, who would join the piano department in the late 1940s, the requirements for the entrance exam were relaxed after World War II, in order to stimulate the prospective students to apply in greater numbers, which was in line with the communists' desire to make music education accessible to all social strata. Trbojević also recalled that prof. Hajek was still the indisputed authority, who ruled the piano department with an iron hand. ${ }^{40}$

\section{Conclusion}

This brief overview of the early days of the Belgrade piano department shows that the pianistic education at the tertiary level in Serbia was not autochthonous, but eclectic, absorbing the legacies of many schools. The beginning of the piano department was very ambitious, which can be deducted both from the high standards for the entrance exams, the effort of the Academy to obtain first-rate instruments that the students could play and practice on, as well as the highly reputable professors hired to teach this instrument both at the secondary and tertiary levels. As summed up by Dubravka Jovičić, an acclaimed pianist and former Dean of the Faculty of Music:

The historical development before the foundation of the Academy showed that our country, hungry for knowledge in the field of art, has always been a fertile soil for the genuine, honest and well-intended seed of knowledge coming from other cultures. Many 'schools' which are sometimes fundamentally different with respect

39 See Perković, “Dva početka. Godine 1937-1957,” 30-32.

40 Cf. Dragoljub - Dragan Šobajić, Dušan Trbojević - Portret umetnika [Dušan Trbojević - Portrait of an Artist] (Novi Sad: Matica srpska, 2003), 29-30. 


\section{to their paths towards the fulfilment of the final goal - the immac- ulate interpretation - have left a strong imprint on the generations of pianists educated at our Academy. ${ }^{41}$}

\section{Bibliography}

Đurić-Klajn, Stana. "Muzičko školovanje u Srbiji do 1914. godine” [Music Education in Serbia until 1914]. In Muzička škola "Mokranjac" 1899-1974 [Music School "Mokranjac" 1899-1974], edited by Vera Zečević, 11-41. Belgrade: Music School "Mokranjac", 1974.

Đurić-Klajn, Stana. Akordi prošlosti [Chords of the Past]. Belgrade: Prosveta, 1981. Hajek, Emil. "Perspektive mladih pijanista" [Perspectives of Young Pianists]. In Dvadeset pet godina Muzičke akademije u Beogradu 1937-1962 [Twenty-Five Years of the Music Academy in Belgrade 1937-1962], edited by Predrag Milošević, 45-53. Belgrade: Music Academy, 1962.

Jovičić, Dubravka. "Katedra za klavir" [The Department for Piano]. In Naših 80 godina - Kultura sećanja [Our 80 Years - The Culture of Remembrance], edited by Ivana Perković, 141-152. Belgrade: Faculty of Music, 2018.

Manojlović, Kosta P., ed. Muzička akademija u Beogradu - Academia artium musicarum Belgradensis [Music Academy in Belgrade], Annual report for the first academic year 1937/38. Belgrade: Music Academy, 1938.

Medić, Ivana, ed. Radio i srpska muzika [Radio and Serbian Music]. Belgrade: Institute of Musicology SASA, 2015.

Milanović, Biljana, ed. Na marginama muzikološkog kanona: kompozitorska generacija Petra Stojanovića, Petra Krstića i Stanislava Biničkog [On the Margins of the Musicological Canon: The Generation of Composers Petar Stojanović, Petar Krstić and Stanislav Binički]. Belgrade: Serbian Musicological Society and the Institute of Musicology SASA, 2019.

Milanović, Biljana. "Reaffirmation of the Forgotten Serbian Music: Three Sonatas of Petar Stojanović for One String Instrument and Piano." CD Sonatas of Petar Stojanović, 5-19. Belgrade: Serbian Musicological Society, 2019.

Milanović, Biljana. "Proučavanje umetničke biografije i muzičkog delovanja Petra Stojanovića: prilog identifikaciji i razmatranju istraživačkih izvora” [The Study of Artistic Biography and Musical Activities of Petar Stojanović: A Contribution to the Identification and Consideration of Research Sources]. Zbornik Matice srpske za scenske umetnosti i muziku 61 (forthcoming).

Milojević, Miloje. “O muzikalnom vaspitanju” [On Music Education], Part I, Prosvetni glasnik 1 (1920): 19-27.

Milojević, Miloje. "O muzikalnom vaspitanju” [On Music Education], Part II, Prosvetni glasnik 3 (1920): 150-156.

41 Jovičić, "Katedra za klavir," 143. 
Milošević, Predrag, ed. Dvadeset pet godina Muzičke akademije u Beogradu 19371962 [Twenty-Five Years of the Music Academy in Belgrade 1937-1962]. Belgrade: Music Academy, 1962.

Music School “Mokranjac” Belgrade. https://mokranjacbg.rs.

Pejović, Radmila. “About School.” Music School "Stanković” Belgrade. http:// msstankovic.edu.rs/aboutschool.html.

Pejović, Roksanda. Koncertni život u Beogradu (1919-1941) [Concert Life in Belgrade (1919-1941)]. Belgrade: Faculty of Music, 2004.

Peno, Vesna, Ivana Vesić, and Aleksandar Vasić, eds. Kosta P. Manojlović (189o1949) and the Idea of Slavic and Balkan Cultural Unification. Belgrade: Institute of Musicology SASA, 2017.

Perković, Ivana. “Trajni déjà vu. Beleške o prvim godinama rada Muzičke akademije u Beogradu, povodom jubileja Fakulteta muzičke umetnosti” [Permanent déjà vu. Notes on the First Years of Work of the Music Academy in Belgrade, on the Occassion of the Anniversary of the Faculty of Music], Zbornik Matice srpske za scenske umetnosti i muziku 57 (2017): 201-225.

Perković, Ivana. “Dva početka. Godine 1937-1957" [Two Beginnings. Years 19371957]. In Naših 80 godina - Kultura sećanja [Our 80 Years - The Culture of Remembrance], edited by Ivana Perković, 21-107. Belgrade: Faculty of $\mathrm{Mu}-$ sic, 2018.

Perković, Ivana, ed. Naših 8o godina - Kultura sećanja [Our 80 Years - The Culture of Remembrance]. Belgrade: Faculty of Music, 2018.

Rajičić, Stanojlo, ed. 125 godina Narodnog pozorišta u Beogradu [125th Anniversary of the National Theatre in Belgrade]. Belgrade: Serbian Academy of Sciences and Arts, 1997.

Sretenović, Mirjana. "Tragična sudbina porodice Botorić” [The Tragic Destiny of the Botorić Family]. Politika, February 28, 2018. http://www.politika.rs/sr/ clanak/399218/Kultura/Tragicna-sudbina-porodice-Botoric.

Stefanović, Dimitrije, ed. Život i delo Stevana Hristića [The Life and Work of Stevan Hristić]. Belgrade: Serbian Academy of Sciences and Arts, 1991.

"Svetislav Stančić.” Croatian Music Information Centre. http:/quercus.mic.hr/ quercus/person/1211.

Šobajić, Dragoljub - Dragan. Dušan Trbojević - Portret umetnika [Dušan Trbojević - Portrait of an Artist]. Novi Sad: Matica srpska, 2003.

Tomašević, Katarina. "Musical Life in Serbia in the First Half of the 2oth Century: Institutions and Repertoire." In Serbian and Greek Art Music: A Patch to Western Music History, edited by Katy Romanou, 33-53. Bristol/Chicago: Intellect Books, 2009.

Various authors. Muzička enciklopedija [Music Encyclopedia]. Zagreb: Jugoslavenski leksikografski zavod, 1971. 
Zdravković, Živojin et al. Beogradska filharmonija 1923-1973 [The Belgrade Philharmonics 1923-1973]. Belgrade: The Belgrade Philharmonics, 1977.

Zečević, Vera. "Škola od 1914. do 1948. godine” [The School from 1914 to 1948]. In Muzička škola "Mokranjac" 1899-1974 [Music School "Mokranjac" 18991974], edited by Vera Zečević, 42-84. Belgrade: Music School "Mokranjac”, 1974. 